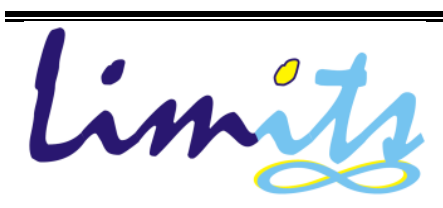

J. Math. and Its Appl.

E-ISSN: 2579-8936

P-ISSN: $1829-605 \mathrm{X}$

Vol. 15, No. 2, Nopember 2018, 113-126

\title{
Aproksimasi Variasional untuk Soliton Onsite pada Persamaan Schrödinger Nonlinier Diskrit Kubik-Kuintik
}

\author{
Riza Asfa ${ }^{1}$, Azzahro Fitri Azadi ${ }^{1}$, Zita Putri Netris ${ }^{1}$, Mahdhivan Syafwan ${ }^{1 *}$ \\ ${ }^{1}$ Jurusan Matematika FMIPA Universitas Andalas Padang Indonesia \\ *e-mail: mahdhivan@sci.unand.ac.id
}

\begin{abstract}
Abstrak
Persamaan Schrödinger nonlinier diskrit (SNLD) kubik-kuintik merupakan persamaan bedadiferensial yang memiliki eksistensi solusi soliton. Pada artikel ini hampiran solusi soliton stasioner dengan konfigurasi bertipe onsite pada persamaan SNLD kubik-kuintik untuk limit anti-continuum ditentukan dengan menggunakan metode aproksimasi variasional (AV). Fungsi penduga yang diusulkan berbentuk eksponensial dengan tiga parameter variasional. Solusi AV yang diperoleh selanjutnya diperiksa validasinya dan dibandingkan dengan solusi numerik. Hasil yang diperoleh menunjukkan bahwa solusi AV valid dan mempunyai kesesuaian yang sangat baik dengan solusi numerik.

Kata kunci: Persamaan Schrödinger nonlinier diskrit kubik-kuintik, soliton onsite, aproksimasi variasional

Abstract

A cubic-quintic discrete nonlinear Schrödinger (DNLS) equation is a difference-differential equation which permits the existence of soliton solution. In this paper, the approximation for stationary soliton solution with onsite-typed configuration in the cubic-quintic DNLS equation for anti-continuum limit is determined by a variational approximation (AV) method. The proposed ansatz is of the form an exponential function with three variational parameters. The obtained VA solutions are then examined its validation and compared with the corresponding numerical solutions. The result shows that the VA solutions are valid and having very good agreement with the numerics.
\end{abstract}

Keywords: Cubic-quintic discrete nonlinear Schrödinger equation, onsite soliton, variational approximation

\section{Pendahuluan}

Persamaan Schrödinger nonliner diskrit (atau disingkat SNLD) merupakan persamaan bedadiferensial (difference-differential) yang secara umum berbentuk [1]

$$
i \dot{\psi}_{n}=-C\left(\psi_{n+1}-2 \psi_{n}+\psi_{n-1}\right)+F\left(\psi_{n+1}, \psi_{n}, \psi_{n-1}\right)
$$

dimana $\psi_{n} \equiv \psi_{n}(t) \in \mathbb{C}$ adalah fungsi gelombang pada waktu $t \in \mathbb{R}^{+}$dan site $n \in \mathbb{Z}, \quad \dot{\psi}_{n}$ menyatakan turunan fungsi $\psi_{n}$ terhadap $t, \quad C$ menyatakan konstanta pengikat (coupling constant) antara dua site yang bersebelahan dan $F$ merupakan suku nonlinier. 
Persamaan SNLD memodelkan berbagai macam fenomena fisis. Beberapa diantaranya dapat dijumpai pada masalah dinamika sistem osilator nonharmonik terikat, perambatan berkas optik pada pandu gelombang nonlinier terikat, dan dinamika kondensasi Bose-Einstein [Bose-Einstein Condentation (BEC)][1] BEC merupakan wujud materi kelima saat mendekati $0^{\circ}$ Kelvin yang secara teori diprediksi oleh S.N Bose dan A. Einstein pada tahun 1925 [2]. Eksperimen pertama yang berhasil membuktikan keberadaan BEC dilakukan oleh Wolfgang Ketterle, Eric Cornell dan Carl Wiemann. Atas prestasi tersebut, mereka dianugrahi hadiah Nobel di bidang fisika pada tahun 2001[3].

Persamaan SNLD (1) menjadi menarik untuk dikaji karena ia memiliki solusi spesial yang dikenal dengan istilah soliton. Solusi ini memiliki profil dan kecepatan yang tetap ketika merambat [4]. Dalam konteks aplikasi dalam bidang optik, soliton dapat direkayasa sebagai pembawa informasi yang dapat merambat pada media dengan jarak tempuh yang sangat jauh tanpa mengalami gangguan yang berarti. Kenyataan ini dinilai sangat penting dalam pengembangan teknologi informasi dan komunikasi di masa depan.

Suku nonlinier $F$ pada persamaan SNLD (1) mempunyai beberapa bentuk, di antaranya $[1]:$

1. Kenonlinieran bertipe kubik:

$$
F_{c u b}=\left|\psi_{n}\right|^{2} \psi_{n}
$$

2. Kenonlinieran bertipe kuintik:

$$
F_{\text {quin }}=\left|\psi_{n}\right|^{4} \psi_{n}
$$

3. Kenonlinieran bertipe Ablowitz-Ladik (AL):

$$
F_{c u b}=-\frac{1}{2}\left|\psi_{n}\right|^{2}\left(\psi_{n+1}+\psi_{n-1}\right)
$$

Persamaan SNLD dengan suku nonlinear kubik (2) dan kuintik (3) dikenal sebagai persamaan yang non-integrable [1]. Pada tahun 1975-1976, Ablowitz dan Ladik [5] memperkenalkan persamaan SNLD dengan suku nonlinier (4) dan menunjukkan bahwa persamaan tersebut integrable.

Untuk menentukan hampiran solusi dari suatu persamaan beda-diferensial yang non-integrable, salah satu pendekatan analitik yang digunakan adalah metode 
aproksimasi variasional (selanjutnya disingkat AV). Metode ini dikembangkan berdasarkan prinsip aksi terkecil (least action) atau dikenal juga sebagai prinsip Hamiltonian yang menyatakan bahwa suatu persamaan gerak ditentukan oleh titik-titik kritis dari aksi (yaitu integral dari Lagrangian terhadap waktu) [6]. Keberhasilan metode ini sangat bergantung pada fungsi penduga (ansatz) yang digunakan dalam menghampiri solusi yang diinginkan.

Pada kasus persamaan SNLD kubik, metode AV telah digunakan oleh Aceves dkk [7] untuk mengaproksimasi solusi soliton onsite, yaitu solusi soliton yang berpusat pada satu site. Kemudian Kaup dkk [8] dan Cuevas dkk [9] menerapkan metode AV untuk menghampiri solusi soliton intersite, yaitu soliton yang berpusat di antara dua site. Fungsi ansatz yang digunakan dalam referensi $[7,8,9]$ tersebut berlaku untuk kasus $C \approx 0$ atau dikenal dengan istilah limit anticontinuum.

Lebih lanjut, metode AV juga diterapkan oleh Syafwan [10] untuk menentukan hampiran solusi soliton onsite pada persamaan SNLD kubik dengan penambahan parametric driving. Eksistensi dan kestabilan soliton pada persamaan ini dikaji pertama kali dengan menggunakan analisis asimtotik dalam referensi [11,12]. Selanjutnya, Putra dkk [13] memakai metode AV untuk menentukan hampiran solusi soliton onsite pada persamaan SNLD nonlokal yang menginterpolasi persamaan SNLD kubik nonlokal dan persamaan SNLD Ablowitz-Ladik nonlokal. Baru-baru ini, Syafwan [14] kembali menggunakan metode AV untuk menentukan hampiran solusi soliton twisted, yaitu soliton intersite berbeda fasa, pada persamaan SNLD kubik dengan penambahan parametric driving.

Hasil-hasil AV yang diperoleh selama ini dikonfirmasi validasinya melalui perbandingan numerik untuk beberapa nilai parameter tertentu. Untuk menjustifikasi validasi AV secara umum, Chong dkk [15] telah mengembangkan suatu teorema yang dapat dijadikan sebagai ukuran validasi hasil AV secara tepat. Chong dkk kemudian mengkonfirmasi bahwa fungsi penduga untuk soliton dengan jumlah parameter yang lebih banyak memberikan aproksimasi yang lebih akurat.

Pada artikel ini metode AV akan diterapkan untuk menentukan hampiran solusi soliton onsite pada persamaan SNLD dengan kenonlinieran bertipe kubik-kuintik, yaitu diberikan oleh [16]

$$
i \dot{\psi}_{n}=-C\left(\psi_{n+1}-2 \psi_{n}+\psi_{n-1}\right)-B\left|\psi_{n}\right|^{2} \psi_{n}+Q\left|\psi_{n}\right|^{4} \psi_{n}
$$

dimana $B$ dan $Q$ berturut-turut menyatakan koefisien kenonlinieran kubik dan kuintik. Persamaan SNLD kubik-kuintik (5) muncul berdasarkan eksperimen 
terkini [17] yang menunjukkan bahwa efek nonlinier pada beberapa material pandu gelombang lebih baik dimodelkan dengan penambahan kenonlinearan kuintik, yaitu ketika $B>0$ dan $Q>$ 0. Pada kasus dua dimensi, persamaan SNLD kubik-kuintik telah dibahas dalam referensi [18]. Kajian pada penelitian ini merupakan pengembangan dari kajian yang dilakukan Chong dkk [16], yaitu menggunakan fungsi ansatz baru dengan jumlah parameter variasional yang lebih banyak.

Artikel ini disusun dengan sistematika sebagai berikut. Pada Bagian 2 dibahas konstruksi aproksimasi variasional. Pada bagian 3 dibahas tentang perbandingan hasil-hasil analitik dengan hasil-hasil numerik. Selanjutnya validasi aproksimasi variasional disajikan pada Bagian 4. Terakhir, pada Bagian 5 dikemukakan kesimpulan dari hasil kajian.

\section{Konstruksi Aproksimasi Variasional}

Langkah-langkah sistematis dari metode AV adalah sebagai berikut [19]:

1. Merumuskan Lagrangian dari persamaan yang ingin ditinjau.

2. Memilih fungsi ansatz (penduga) yang sesuai, yang memuat sejumlah hingga parameter (disebut sebagai parameter variasional).

3. Mensubstitusikan fungsi ansatz ke dalam Lagrangian dan kemudian menyelesaikan penjumlahannya (untuk sistem diskrit) atau integrasinya (untuk sistem kontinu).

4. Menentukan titik-titik kritis untuk parameter variasional dengan menyelesaikan persamaan Euler-Lagrange terkait.

Sebagai langkah pertama, dirumuskan terlebih dahulu Lagrangian dari sistem (5). Hal ini diberikan oleh lema berikut.

Lema 1. Lagrangian dari persamaan (5) diberikan oleh

$$
L=\frac{i}{2}\left(\bar{\psi}_{n} \dot{\psi}_{n}-\psi_{n} \dot{\bar{\psi}}_{n}\right)+C\left(\bar{\psi}_{n} \psi_{n+1}+\psi_{n} \bar{\psi}_{n+1}-2\left|\psi_{n}\right|^{2}\right)+\frac{B}{2}\left|\psi_{n}\right|^{4}-\frac{Q}{3}\left|\psi_{n}\right|^{6},
$$

dimana $\bar{\psi}_{n}$ menyatakan kompleks konjugat dari $\psi_{n}$.

Bukti. Persamaan Euler-Lagrange untuk sistem yang ditinjau adalah

$$
\frac{\partial L}{\partial \psi_{n}}-\frac{d}{d t} \frac{\partial L}{\partial \dot{\psi}_{n}}=0
$$

Berikut ini akan ditunjukkan bahwa (5) dengan Lagrangian (6) akan menghasilkan persamaan (5). Perhatikan bahwa untuk suatu $n=m \in \mathbb{Z}$, persamaan (6) dapat ditulis 


$$
\begin{aligned}
& L=\cdots+\left[\frac{i}{2}\left(\bar{\psi}_{m-1} \dot{\psi}_{m-1}-\psi_{m-1} \dot{\bar{\psi}}_{m-1}\right)+C\left(\bar{\psi}_{m-1} \psi_{m}+\psi_{m-1} \bar{\psi}_{m}-2\left|\psi_{m-1}\right|^{2}\right)+\frac{B}{2}\left|\psi_{m-1}\right|^{4}-\right. \\
& \left.\frac{Q}{3}\left|\psi_{m-1}\right|^{6}\right]+\left[\frac{i}{2}\left(\bar{\psi}_{m} \dot{\psi}_{m}-\psi_{m} \dot{\bar{\psi}}_{m}\right)+C\left(\bar{\psi}_{m} \psi_{m+1}+\psi_{m} \bar{\psi}_{m+1}-2\left|\psi_{m}\right|^{2}\right)+\frac{B}{2}\left|\psi_{m}\right|^{4}-\frac{Q}{3}\left|\psi_{m}\right|^{6}\right]+\cdots
\end{aligned}
$$

Turunan $L$ terhadap $\psi_{m}$ dan terhadap $\dot{\psi}_{m}$ berturut-turut diberikan oleh

$$
\begin{gathered}
\frac{\partial L}{\partial \psi_{m}}=C \bar{\psi}_{m-1}-\frac{i}{2} \dot{\bar{\psi}}_{m}+C \bar{\psi}_{m+1}-2 C \bar{\psi}_{m}+B \bar{\psi}_{m}{ }^{2}-Q\left(\psi_{m} \bar{\psi}_{m}\right)^{2} \bar{\psi}_{m}, \\
\frac{\partial L}{\partial \dot{\psi_{m}}}=\frac{i}{2} \bar{\psi}_{m} \Rightarrow \frac{d}{d t} \frac{\partial L}{\partial \dot{\psi}_{m}}=\frac{i}{2} \dot{\bar{\psi}}_{m} .
\end{gathered}
$$

Karena $\bar{\psi}_{m} \psi_{m}=\left|\psi_{m}\right|^{2}$, maka dari persamaan (9) dan (10), persamaan (7) menjadi

$$
-i \dot{\bar{\psi}}_{m}=-C\left(\bar{\psi}_{m+1}-\psi_{n} 2 C \bar{\psi}_{m}-\bar{\psi}_{m-1}\right)-B\left|\psi_{n}\right|^{2} \bar{\psi}_{m}+Q\left|\psi_{n}\right|^{4} \bar{\psi}_{m}
$$

Dengan mengenakan konjugat di kedua sisi persamaan (11), kemudian hasilnya dikalikan dengan - 1 dan indeks $m$ diganti dengan $n$, maka diperoleh

$$
i \dot{\bar{\psi}}_{n}=-C\left(\psi_{n+1}-2 \psi_{n}-\psi_{n-1}\right)-B\left|\psi_{n}\right|^{2} \psi_{n}+Q\left|\psi_{n}\right|^{4} \psi_{n}
$$

yang merupakan persamaan (5).

Solusi soliton diskrit stasioner dapat diperoleh dengan mensubstitusikan $\psi_{n}(t)=u_{n} e^{-i \mu t}$, dimana $\mu$ menyatakan frekuensi osilasi, ke persamaan SNLD (5) sehingga didapatkan

$$
-C\left(u_{n+1}-2 u_{n}+u_{n-1}\right)-B\left|u_{n}\right|^{2} u_{n}+Q\left|u_{n}\right|^{4} u_{n}-\mu u_{n}=0 .
$$

Secara umum solusi $u_{n}$ bernilai kompleks, namun analisis persamaan (13) untuk soliton diskrit yang memenuhi $u_{n} \rightarrow 0$ ketika $n \rightarrow \pm \infty$, dapat disederhanakan tanpa mengurangi keumuman dengan meninjau solusi yang bernilai riil saja [16]. Dengan demikian persamaan (13) menjadi

$$
-C\left(u_{n+1}-2 u_{n}+u_{n-1}\right)-B u_{n}^{3}+Q u_{n}^{5}-\mu u_{n}=0
$$

Dalam hal ini, terdapat tak hingga banyaknya konfigurasi untuk soliton diskrit yang dimaksud. Namun dalam artikel ini hanya ditinjau solusi soliton onsite, yaitu soliton yang berpusat pada satu site dan memenuhi $u_{n}=u_{-n}$.

Selanjutnya sebagai langkah kedua, dipilih fungsi ansatz yang sesuai, yang memuat sejumlah parameter. Dalam mengaproksimasi soliton onsite stasioner pada persamaan SNLD kubik-kuintik (14), Chong dkk [16] mengusulkan fungsi ansatz berikut:

$$
u_{n}=A e^{-\eta|n|} \text {, }
$$

dimana $A$ dan $\eta$ adalah parameter variasional yang berturut-turut menyatakan amplitudo dan lebar soliton. 
Pada artikel ini dipilih fungsi ansatz berikut:

$$
u_{n}= \begin{cases}A e^{-\eta(|n|-1)}, & n \neq 0 \\ E, & n=0 .\end{cases}
$$

dimana tambahan parameter $E$ yang merepresentasikan amplitudo soliton pada site $n=0$ dapat mengakomodir profil soliton yang semakin menyempit ke site $n=0$ ketika $C \rightarrow 0$. Dibandingkan dengan ansatz Chong (15), ansatz (16) yang diusulkan ini diharapkan dapat meningkatkan akurasi aproksimasi variasional pada kasus limit anti-continuum.

Langkah ketiga adalah mensubstitusi ansatz (16) ke bagian stasioner Lagrangian (6), kemudian menyelesaikan penjumlahannya. Hasil penjumlahan ini dinamakan Lagrangian efektif. Dengan menggunakan bantuan Maple, diperoleh Lagrangian efektif sebagai berikut:

$$
\begin{aligned}
& L_{\mathrm{eff}}=-\frac{1}{6} \frac{1}{\left(e^{6 \eta}-1\right)\left(e^{2 \eta}+1\right)}\left(24 C A E+4 e^{6 \eta} A^{6} Q+12 C E^{2} e^{6 \eta}+48 A^{2} C e^{4 \eta}+6 E^{2} \mu-2 Q E^{6}+3 B E^{4}-3 B E^{4} e^{6 \eta}-\right. \\
& 48 A^{2} C e^{5 \eta}-48 A^{2} C e^{3 \eta}+2 Q E^{6} e^{6 \eta}-12 A^{2} e^{2 \eta} \mu-6 E^{2} \mu e^{8 \eta}-24 A^{2} C e^{7 \eta}-3 B E^{4} e^{8 \eta}-2 Q E^{6} e^{2 \eta}-24 A^{2} C e^{\eta}- \\
& 6 E^{2} \mu e^{6 \eta}+6 E^{2} \mu e^{2 \eta}+12 C E^{2} e^{8 \eta}-24 A^{2} \mu e^{6 \eta}-24 C A E e^{8 \eta}-12 C E^{2} e^{2 \eta}-12 C E^{2}-12 e^{8 \eta} A^{2} \mu+4 e^{8 \eta} A^{6} Q- \\
& 6 e^{6 \eta} A^{4} B+3 B E^{4} e^{2 \eta}+24 A^{2} C e^{2 \eta}+48 A^{2} C e^{6 \eta}+24 e^{8 \eta} A^{2} C-6 e^{8 \eta} A^{4} B+2 Q E^{6} e^{8 \eta}+24 C A E e^{2 \eta}-24 C A e^{6 \eta}- \\
& \left.24 A^{2} \mu e^{4 \eta}-6 A^{2} e^{4 \eta} B\right) .
\end{aligned}
$$

Berdasarkan prinsip variasional, Lagrangian efektif mencapai nilai kritis pada persamaan Euler-Lagrange. Untuk kasus stasioner, hal ini mengakibatkan

$$
\frac{\partial L_{\mathrm{eff}}}{\partial A}=\frac{\partial L_{\mathrm{eff}}}{\partial E}=\frac{\partial L_{\mathrm{eff}}}{\partial \eta}=0
$$

Dengan mensubstitusikan Lagrangian efektif (17) ke persamaan (18), didapatkan sistem persamaan variasional berikut:

$$
\begin{aligned}
\mathcal{A}_{1}+\mathcal{A}_{2}+\mathcal{A}_{3} & =0, \\
\mathcal{B}_{1}+\mathcal{B}_{2}+\mathcal{B}_{3}+\mathcal{B}_{4} & =0, \\
\mathcal{C}_{1} & =0,
\end{aligned}
$$

dimana

$$
\begin{aligned}
& \mathcal{A}_{1}=-4 C E-4 e^{6 \eta} A^{5} Q-16 A C e^{4 \eta}+16 A C e^{5 \eta}+16 A e^{3 \eta}+4 A e^{2 \eta}+8 A C e^{7 \eta}, \\
& \mathcal{A}_{2}=8 A C e^{\eta}+8 A \mu e^{6 \eta}+4 C E e^{8 \eta}+4 e^{8 \eta} A \mu-4 e^{8 \eta} A^{5} Q+4 e^{6 \eta} A^{3} B-8 A C e^{2 \eta}, \\
& \mathcal{A}_{3}=-16 A C e^{6 \eta}-8 e^{8 \eta} A C+4 e^{8 \eta} A^{3} B-4 C E e^{2 \eta}+4 C E e^{6 \eta}+8 A \mu e^{4 \eta}+4 A^{3} e^{4 \eta} B, \\
& \mathcal{B}_{1}=4 e^{\eta} A^{2}\left(-18 C e^{8 \eta}-4 \mu e^{3 \eta}-8 \mu e^{5 \eta}-18 C e^{6 \eta}+16 e^{5 \eta}-12 C e^{4 \eta}+2 e^{7 \eta} A^{4} Q\right), \\
& \mathcal{B}_{2}=4 e^{\eta} A^{2}\left(2 C e^{13 \eta}-3 e^{7 \eta}\right) A^{2} B+8 e^{3 \eta} C+e^{5 \eta} A^{4} Q-C e^{14 \eta}-2 A^{2} e^{9 \eta} B-C e^{11 \eta} A^{2} B, \\
& \mathcal{B}_{3}=4 e^{\eta} A^{2}\left(-5 C e^{2 \eta}+2 C e^{\eta}-A^{2} e^{3 \eta} B-12 C e^{10 \eta}+Q A^{4} e^{9 \eta}-e^{13 \eta} \mu-4 \mu e^{11 \eta}-10 e^{7 \eta} \mu,\right. \\
& \mathcal{B}_{4}=4 e^{\eta} A^{2}\left(-e^{\eta} \mu+20 C e^{7 \eta}-2 A^{2} e^{5 \eta} B\right)+8 C e^{11 \eta}+16 C e^{9 \eta}-8 e^{9 \eta} \mu-5 \mu e^{9 \eta}-5 C e^{12 \eta}, \\
& \mathcal{C}_{1}=-2 Q E^{5}+2 E \mu-4 C E+4 C A+2 B E^{3} .
\end{aligned}
$$


Langkah terakhir dari metode AV adalah menentukan titik-titik kritis untuk parameter variasional. Karena kompleksitas perhitungan, nilai parameter variasional $A, E, \eta$ yang diperoleh sebagai solusi dari sistem persamaan (19)-(21) untuk nilai $C, B, Q, \mu$ yang diberikan dapat dihitung secara numerik dengan menggunakan metode Newton-Raphson.

\section{Perbandingan Hasil Analitik dengan Hasil Numerik}

Pada bagian ini hasil-hasil yang diperoleh dengan menggunakan metode AV akan dibandingkan dengan hasil-hasil numerik. Karena yang ditinjau kasus stasioner, maka solusi numerik untuk soliton onsite diperoleh dengan menyelesaikan persamaan (14). Di sini solusi numerik ditentukan dengan menggunakan metode Newton-Raphson yang dihitung pada domain $n \in[-N, N]$, dengan $N \in \mathbb{Z}$ yang nilainya cukup besar. Karena soliton mempunyai ekor yang asimtotik ke nol, maka pada skema numerik digunakan syarat batas $u_{ \pm(N+1)}=u_{ \pm(N)}$.

Sebagai contoh ilustrasi, pada Gambar 1 diperlihatkan perbandingan antara solusi soliton onsite yang diperoleh dari perhitungan numerik dengan yang dihasilkan dari aproksimasi variasional untuk nilai-nilai parameter $\mu=0.5 ; B=2 ; Q=0.1 ; 0.8$ dan $C=0.04 ; 0.09 ; 0.1$. Pada Gambar 1 juga ditampilkan solusi untuk nilai-nilai parameter variasional $A, E$, dan $\eta$ yang diperoleh dengan menyelesaikan sistem persamaan (19)-(21) secara numerik untuk nilai $\mu, C, B$ dan Q yang diberikan. Dapat diamati dari Gambar 1 bahwa hampiran solusi soliton AV memiliki kesesuaian yang sangat bagus dengan solusi numerik, dimana tingkat keakuratannya lebih baik untuk nilai $C$ yang semakin kecil. Hal ini konsisten dengan kasus yang ditinjau, yaitu untuk limit anti-continuum.

\section{Validasi Aproksimasi Variasional}

Validasi hasil aproksimasi untuk soliton diskrit pada persamaan SNLD (13) didasarkan pada justifikasi yang dilakukan oleh Chong dkk [15]. Untuk mengukur keakuratan solusi variasional dari persamaan SNLD (13), definisikan terlebih dahulu

$$
R_{n}(u)=-C\left(u_{n+1}-2 u_{n}+u_{n-1}\right)-B u_{n}^{3}+Q u_{n}^{5}-\mu u_{n}
$$

Perhatikan bahwa jika $u$ solusi eksak, maka $R_{n}(u)$ akan bernilai nol untuk setiap $n$. Dengan demikian solusi variasional akan mendekati solusi eksak apabila $R_{n}(u) \rightarrow 0$ untuk setiap $n$.

Validasi aproksimasi variasional untuk soliton onsite pada persamaan SNLD kubik-kuintik stasioner (14) diberikan dalam proposisi berikut.

Proposisi 1. Misalkan $u_{*}$ adalah solusi variasional soliton onsite dari persamaan SNLD kubikkuintik stasioner (14) yang dinyatakan dengan ansatz (16) dimana parameter variasional $\eta, A$, 
E memenuhi persamaan (19), (20), (21). Maka terdapat $C_{0}, K>0$ sedemikian sehingga untuk setiap $C \in\left(0, C_{0}\right)$, persamaan SNLD kubik-kuintik stasioner (13) memiliki solusi u yang memenuhi

$$
\left\|u-u_{*}\right\|_{l_{2}} \leq K C^{4} .
$$




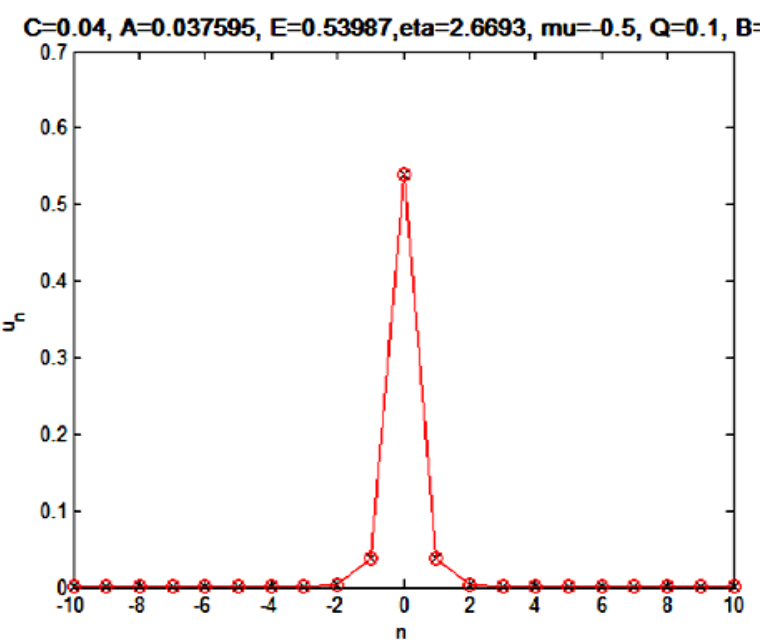

(a)

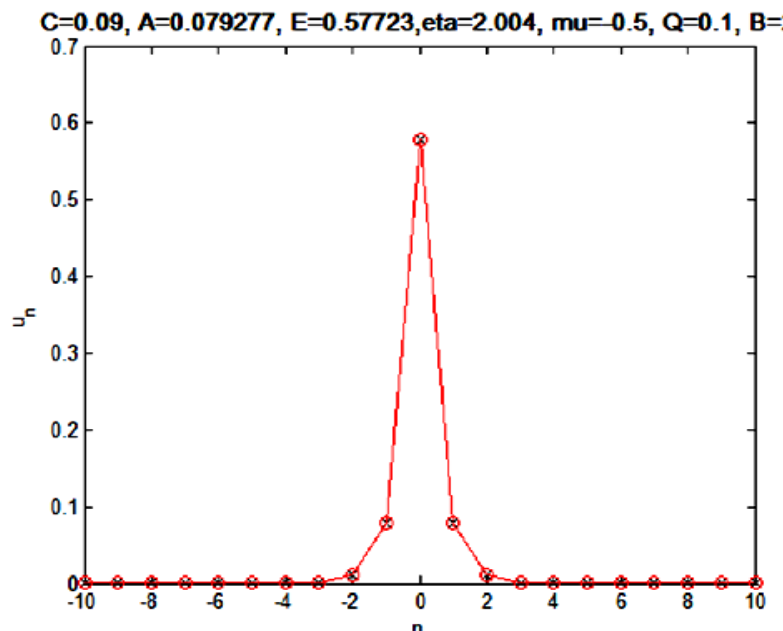

(c)

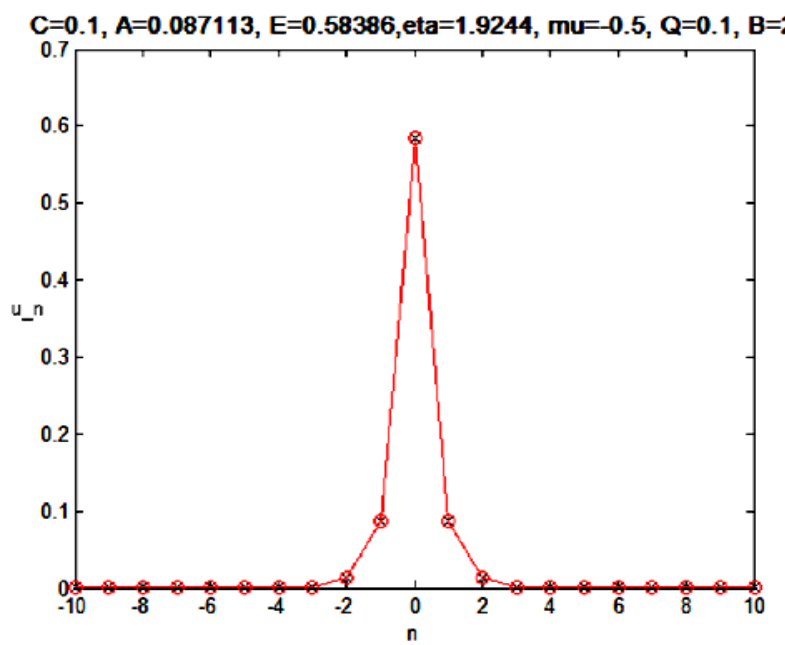

(e)

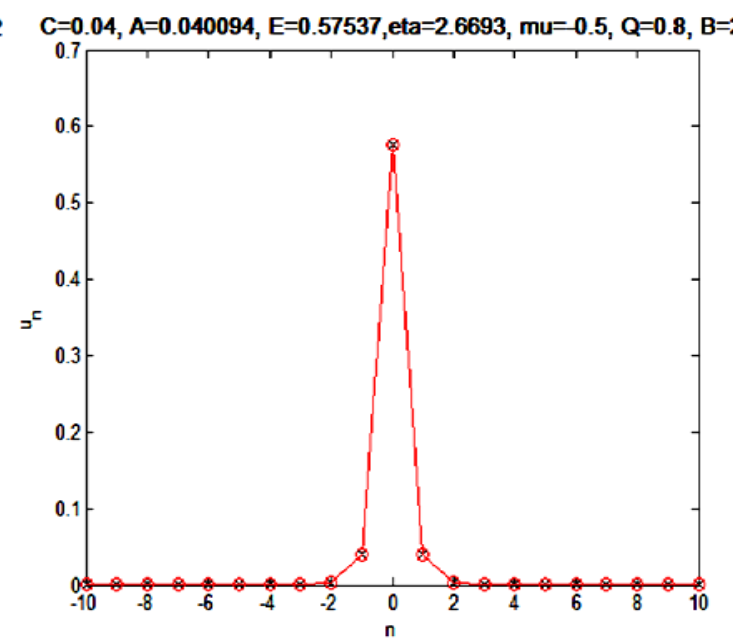

(b)

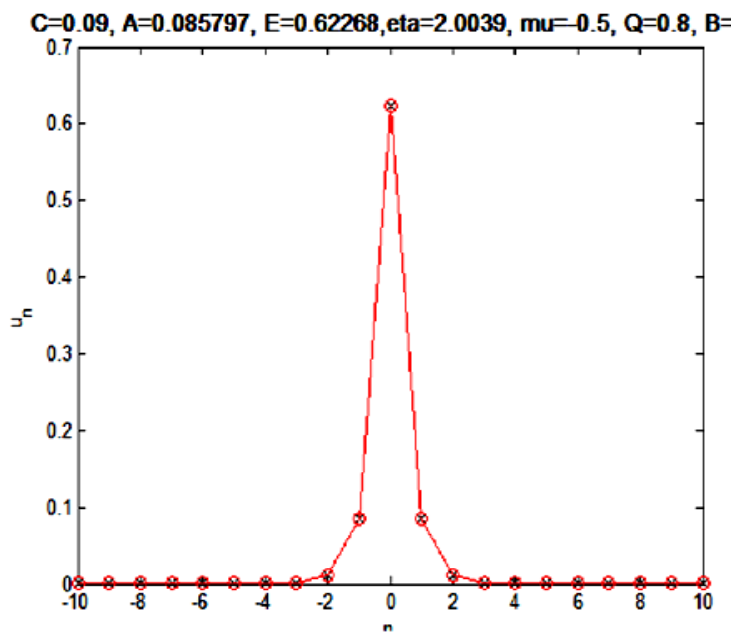

(d)

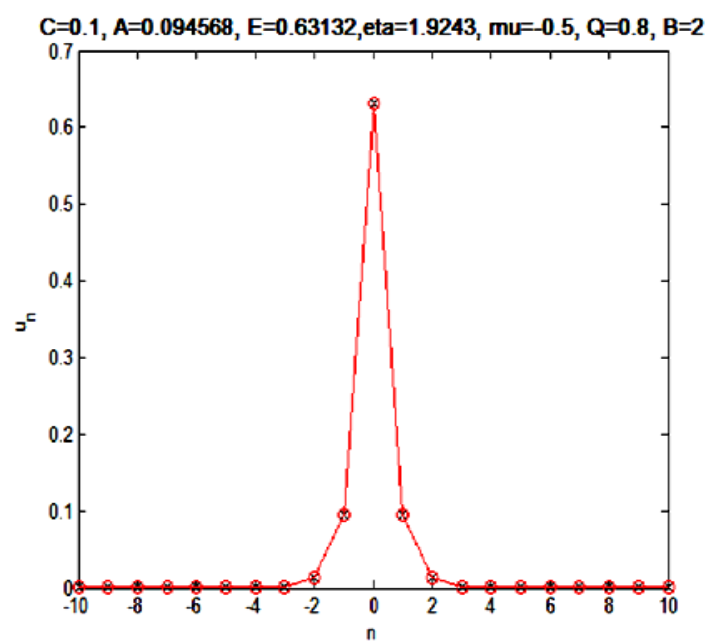

(f)

Gambar 1. Perbandingan solusi soliton onsite yang diperoleh secara numerik (garis-bulat) dan aproksimasi variasional (garis-silang) untuk beberapa nilai $C, B, Q$, dan $\mu$. 
Bukti. Perhatikan bahwa laju penurunan eksponensial soliton diskrit memenuhi teori linier persamaan beda, sehingga solusi untuk parameter $\eta$ dapat diperoleh dengan mensubstitusikan $u_{n}=p e^{-\eta n}$, dimana $p$ suatu konstanta tak-nol, ke bagian linier dari persamaan (22), yaitu

$$
-C\left(u_{n+1}-2 u_{n}+u_{n-1}\right)-\mu u_{n}=0,
$$

sehingga didapat

$$
-C\left(e^{-\eta}+e^{\eta}\right)=2 C-\mu \Rightarrow \eta=\operatorname{arccosh}\left(\frac{2 C-\mu}{2 C}\right) .
$$

Fungsi $e^{\eta}$ dapat dijabarkan dalam deret Taylor di $C \approx 0$ sebagai berikut:

$$
e^{\eta}=\frac{C}{\mu}-2 \frac{C^{2}}{\mu^{2}}+5 \frac{C^{3}}{\mu^{3}}-14 \frac{C^{4}}{\mu^{4}}+42 \frac{C^{5}}{4}+\mathcal{O}\left(C^{6}\right) .
$$

Misalkan parameter $A$ dan $E$ dapat ditulis dalam bentuk ekspansi

$$
\begin{aligned}
& A=a_{0}+a_{1} C+a_{2} C^{2}+a_{3} C^{3}+\mathcal{O}\left(C^{4}\right), \\
& E=b_{0}+b_{1} C+b_{2} C^{2}+b_{3} C^{3}+\mathcal{O}\left(C^{4}\right),
\end{aligned}
$$

dimana $a_{i}$ dan $b_{i}$ merupakan koefisien-koefisien yang akan dicari nilainya. Hal ini dilakukan dengan mensubstitusi persamaan (26), (27) dan (28) ke persamaan (19) dan (20), kemudian mengelompokkan suku-sukunya berdasarkan pangkat $C$.

Selanjutnya ansatz (16) disubstitusikan ke persamaan (22), sehingga diperoleh

$$
R_{n}(u)= \begin{cases}A\left(-C e^{-\eta(|n+1|-1)}+2 C e^{-\eta(|n|-1)}-C e^{-\eta(|n-1|-1)}-B A^{2} e^{-3 \eta(|n|-1)}+\right. & \\ \left.Q A^{4} e^{-\eta(|n|-1)}-\mu e^{-\eta(|n|-1)}\right), & n \leq-2 \\ C E+2 C A-C A e^{-\eta}-B A^{3}+Q A^{5}-\mu A, & n=0 \\ -2 C A+2 C E-B E^{3}+Q E^{5}-\mu E, & n=1 \\ -C E+2 C A-C A e^{-\eta}-B A^{3}-Q A^{5}-\mu A, & \\ A\left(-C e^{-\eta(|n+1|-1)}+2 C e^{-\eta(|n|-1)}-C e^{-\eta(|n-1|-1)}-B A^{2} e^{-3 \eta(|n|-1)}+\right. & n \geq 2 \\ \left.Q A^{4} e^{-\eta(|n|-1)}-\mu e^{-\eta(|n|-1)}\right), & \end{cases}
$$

Dengan mensubstitusikan ekspansi (26), (27), (28) ke persamaan (29), dihasilkan

$$
\begin{aligned}
& R_{0}(u)=0, \\
& R_{|n|=1}(u)=\mathcal{O}\left(C^{4}\right), \\
& R_{|n| \geq 2}(u)=\mathcal{O}\left(C^{3|n|}\right) .
\end{aligned}
$$

Perhatikan bahwa barisan $\left\{R_{i}(u)\right\}_{i=1}^{\infty}$ konvergen ke 0 . Akibatnya $\left|R_{1}\right|^{2}+\left|R_{2}\right|^{2}+\cdots$ konvergen atau $\sum_{k=1}^{\infty}\left|R_{k}\right|^{2}<\infty$. Hal ini menjelaskan bahwa $R_{i}(u)$ ada di ruang $l_{2}$ dengan norm $\|R(u)\|_{l_{2}}=\sqrt{\left|R_{1}\right|^{2}+\left|R_{2}\right|^{2}+\cdots}$. Lebih lanjut, dari (30) diperoleh

$$
\|R(u)\|_{l_{2}}=\mathcal{O}\left(C^{4}\right) \text { ketika } C \rightarrow 0 .
$$


Selanjutnya misalkan $S=\{0\}, e_{0}=(\ldots, 0,0,0,1,0,0,0, \ldots)$, dan $\sigma_{0}=c$, untuk suatu $c>0$. Untuk kasus soliton diskrit onsite, dapat ditunjukkan bahwa solusi variasional $u_{*}$ yang dinyatakan oleh ansatz (16) memenuhi

$$
\lim _{C \rightarrow 0}\left\|u_{*}-\sigma_{0} e_{0}\right\|_{l_{2}}=0 .
$$

Berdasarkan justifikasi yang diberikan oleh Chong dkk [15], maka terdapat $C_{0}, K>0$ dan solusi tunggal $u$ dari persamaan SNLD kubik-kuintik stasioner (13) dengan $C \in\left(0, C_{0}\right)$ sedemikian sehingga berlaku

$$
\left\|u-u_{*}\right\|_{l_{2}} \leq K C^{4}
$$

Dengan demikian Proposisi 1 terbukti.

Karena solusi eksak tidak diketahui, maka dalam implementasinya kuantitas $\| u-$ $u_{*} \|_{l_{2}}$ dapat dihampiri oleh

$$
\text { galat }=\left\|u_{\text {num }}-u_{*}\right\|
$$

dimana $u_{\text {num }}$ adalah solusi numerik dan $u_{*}$ adalah solusi variasional.

Sebagai ilustrasi, misalkan akan diperiksa validasi solusi variasional untuk $B=2, \mu=0.5$ dengan dua nilai $Q$ yang berbeda, yaitu $Q=0.1$ dan $Q=0.8$. Grafik dari galat (40) terhadap $C$ diberikan pada Gambar 2. Dari gambar dapat dilihat bahwa nilai galat semakin besar ketika $C$ membesar. Untuk mengetahui fungsi dari kurva galat tersebut, dilakukan pencocokan kurva (best power fit) yang memberikan hasil $f(C)=0.65808 C^{5.7172}$ (untuk $Q=0.1$ ) dan $f(C)=$ $0.97495 C^{5.7818}$ (untuk $Q=0.8$ ). Perhatikan bahwa hasil-hasil ini memenuhi persamaan (33) pada Proposisi 1. Hal ini mengkonfirmasi bahwa solusi AV untuk soliton onsite dengan menggunakan ansatz (16) adalah valid.
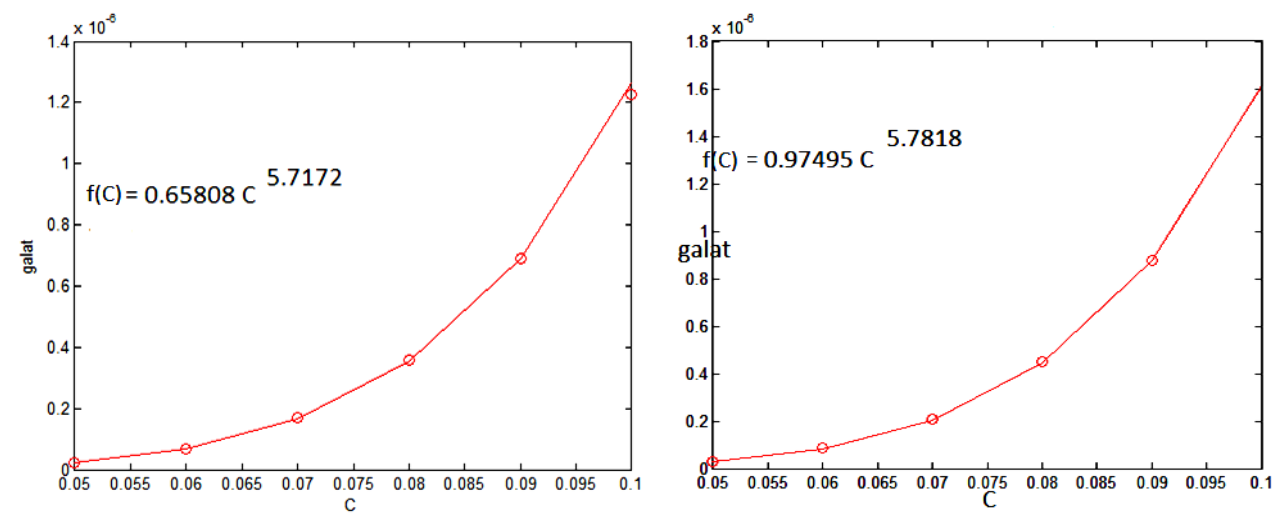

Gambar 2. Nilai galat antara solusi variasional dan solusi numerik terhadap $C$ untuk $\mu=0.5, B=2$, dan dua nilai $Q$, yaitu $Q=0.1$ (kiri) dan $Q=0.8$ (kanan). 
Untuk membandingkan hasil tersebut dengan hasil AV yang diperoleh dari ansatz Chong (15), maka dengan cara melakukan perhitungan yang sama dengan sebelumnya, dapat dicari $\|R(u)\|_{l^{2}}$ dimana $u$ adalah ansatz (15). Selanjutnya dapat diplot galat antara solusi numerik dan variasional seperti yang didefinisikan pada persamaan (34). Hasil perhitungan variasional memberikan

$$
\|R(u)\|_{l^{2}}=O\left(C^{3}\right)
$$

dan plot galat diberikan pada Gambar 3 untuk $\mu=0.5, B=2$ dan $Q=0.1 ; 0.8$. Dengan menggunakan pencocokan kurva (best power fit) untuk kurva galat pada Gambar 3, diperoleh $f(C)=0,8992 C^{3,3399}$ (untuk $Q=0.1$ ) dan $f(C)=1.3219 C^{3.4045}$ (untuk $Q=0.8$ ). Dari persamaan (35) dan Gambar 3 dapat disimpulkan bahwa solusi variasional yang diperoleh dari ansatz (16) lebih akurat daripada ansatz Chong (15).
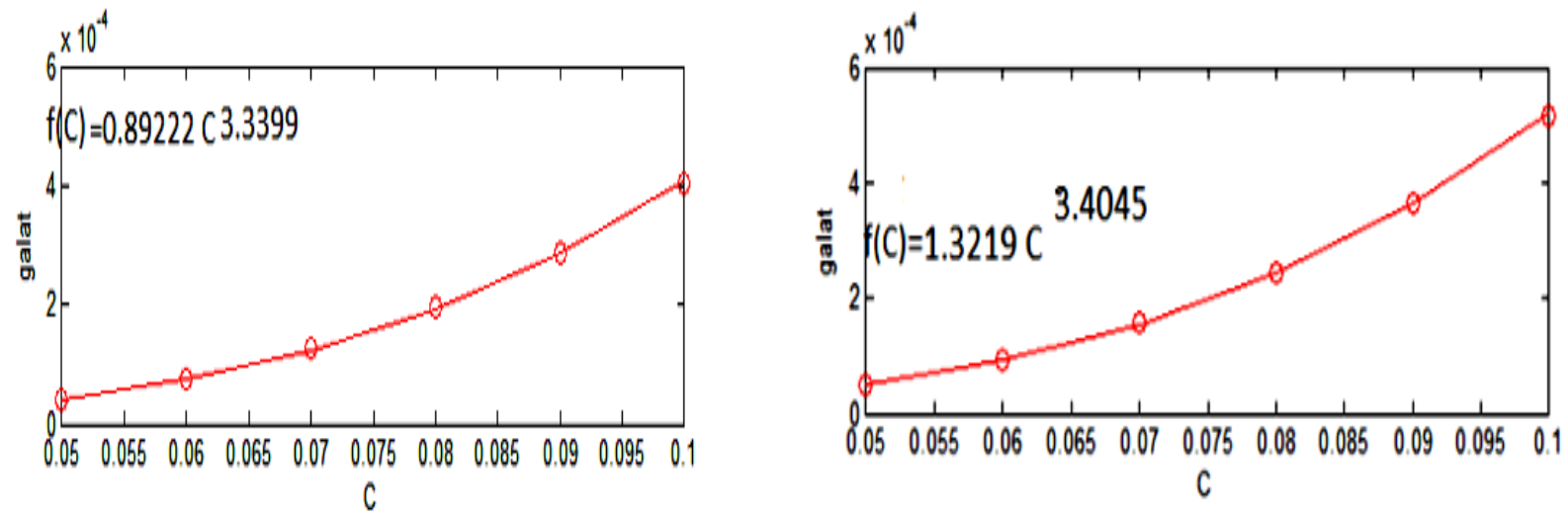

Gambar 3. Nilai galat antara solusi variasional dan solusi numerik terhadap $C$ untuk $\mu=0.5, B=2$, dan dua nilai $Q$, yaitu $Q=0.1$ (kiri) dan $Q=0.8$ (kanan).

\section{Simpulan}

Pada artikel ini telah dicari aproksimasi variasional untuk soliton onsite pada persamaan SNLD kubik-kuintik dengan menggunakan fungsi ansatz baru. Solusi AV yang diperoleh menunjukkan kesesuaian yang sangat baik dengan solusi yang diperoleh secara numerik untuk kasus limit anti-continuum. Solusi AV tersebut kemudian diuji validasinya berdasarkan justifikasi yang dilakukan oleh Chong dkk [15], dan diperoleh bahwa solusi AV yang dihasilkan adalah valid. Dibandingkan dengan fungsi ansatz yang digunakan Chong dkk [16] ,fungsi ansatz baru yang diusulkan dalam artikel ini menghasilkan aproksimasi yang lebih baik. 


\section{Daftar Pustaka}

[1] P. G. Kevrekidis, "Discrete Nonlinear Schrödinger Equation: Mathematical Analysis, Numerical Computations and Physical Perspectives," Springer Tracts in Modern Physics, Volume 54. Springer, 2009.

[2] J.T. Mendonça dan Hugo Terças, "Physics of Ultra-Cold Matter: Atomic Clouds, BoseEinstein Condensates and Rydberg Plasmas," Springer, New York, 2013.

[3] A. Nobel, "The Nobel Prize in Physics 2001," 2001. [Online]. Available: https://www.nobelprize.org/prizes/physics/2001/advanced-information/. [Accessed: 10Feb-2018].

[4] P. G. Drazin dan R. S. Johnson, "Soliton: An Introduction," Cambridge University Press, Cambridge. 1989.

[5] M. J. Ablowitz dan J. F. Ladik, "Nonlinear differential - difference equations and Fourier analysis", J.Math Phys, vol. 16, pp. 598, 1976.

[6] K. W. Cassel, Variational methods with applications in science and engineering, Cambridge University Press, Cambridge, 2013.

[7] A. B. Aceves, C. De Angelis, T. Peschel, R. Muschall, F. Lederer, S. Trillo and S. Wabnitz, "Discrete self-trapping, soliton interactions, and beam steering in nonlinear waveguide arrays," Phys. Rev. E, vol. 53, no. 1, pp. 1172-1189, 1996.

[8] D. J. Kaup, "Variational solutions for the discrete nonlinear Schrödinger equation," Math. Comput. Simul., vol. 69, no. 3-4, pp. 322-333, 2005.

[9] J. Cuevas, G. James, P. G. Kevrekidis, B.A. Malomed dan B. Sánchez-Rey, "Approximation of solitons in the discrete NLS equation," J. Nonlinear Math. Phys, vol. 15, pp. 124, 2008.

[10] Syafwan, M., "Variational approximations for solitons in a parametrically driven discrete nonlinear Schrödinger equation," Prosiding Seminar Nasional Matematika dan Pendidikan Matematika. 31 Oktober 2012, Universitas Andalas, Padang, Indonesia. Hal. 52-58, 2012.

[11] Susanto, H, Q. E. Hoq dan P. G. Kevrekidis," Stability of discrete solitons in the presence of parametric driving," Phys. Rev. E. 74: 067601, 2006.

[12] Syafwan, M, H. Susanto dan S. M. Cox.," Discrete solitons in electromechanical resonators," Phys. Rev. E. 81: 026207, 2010.

[13] P. S. Matematika and U. Andalas, "Aproksimasi variasional untuk solusi " soliton pada persamaan schr odinger nonlinier diskrit nonlokal," vol. 5, no. 3, pp. 40-46. 
[14] Syafwan, M, Efendi, N. Arifin, "Variational approximations for twisted solitons in a parametrically driven discrete nonlinear Schrödinger equation". Journal of Physics: Conf. Series 983: 012145, 2018.

[15] C. Chong, D. E. Pelinovsky, and G. Schneider, "On the validity of the variational approximation in discrete nonlinear Schrödinger equations," Phys. D Nonlinear Phenom., vol. 241, no. 2, pp. 115-124, 2011.

[16] C. Chong and D. E. Pelinovsky, "Variational approximations of bifurcations of asymmetric solitons in cubic-quintic nonlinear schrödinger lattices," Discret. Contin. Dyn. Syst. - Ser. S, vol. 4, no. 5, pp. 1019-1031, 2011.

[17] G. Boudebs, S. Cherukulappurath, H. Leblond, J. Troles, F. Smektala, and F. Sanchez, "Experimental and theoretical study of higher-order nonlinearities in chalcogenide glasses," Opt. Commun., vol. 219, no. 1-6, pp. 427-433, 2003.

[18] C. Chong, R. Carretero-Gonz_alez, B. A. Malomed dan P. G. Kevrekidis, "Multistable solitons in higher-dimensional cubic-quintic nonlinear Schrödinger lattices", Physica D, vol. $238,126-136,2009$

[19] D. J. Kaup dan T. K. Vogel, "Quantitative Measurement of Variational Approximations " Phys. Lett. A, vol. 362, pp. 53-66, 2007. 